Карнаух C. Г.

\title{
ПЕРСПЕКТИВНІ ТЕХНОЛОГІЇ ЗАГОТІВЕЛЬНОГО ВИРОБНИЦТВА ТА ОБЛАДНАННЯ ДЛЯ ЇХ РЕАЛІЗАЦЇ̈
}

В Україні середня трудомісткість заготівельних робіт у машинобудуванні становить $40 . . .45 \%$ загальної трудомісткості виробництва машин. Головна тенденція у розвитку заготівельного виробництва направлена на зниження трудомісткості механічної обробки при виготовленні деталей машин за рахунок підвищення точності їхньої форми й розмірів.

Тому актуальним є завдання вибору методу отримання заготовок, який забезпечить мінімальну собівартість при задовільній якості продукції. Рішення цього питання може бути різноманітним, вибір одного з варіантів ускладнений й часто заснований на інженерній інтуїції й практичному досвіді. Крім того, прийняття рішень відбувається в умовах виробничих багатофакторних задач, обмежень матеріальних ресурсів, економічних можливостей, енергетичних ресурсів, наявності кваліфікованих кадрів, транспортних витрат, можливостей кооперації, часу для підготовки виробництва та ін.

Мета роботи - на основі аналізу існуючих способів розділення сортового прокату на мірні заготовки, запропонувати нові способи і схеми розділення та обладнання для їх реалізації.

Для вирішення цих питань запропонована класифікація способів розділення сортового прокату на мірні заготовки за основними класифікаційними ознаками: за відходністю; за схемою навантаження (деформації); за характером навантаження; за способом інтенсивності передачі навантаження від інструменту до заготовки; за напрямком руху інструменту. Класифікація наведена на рис. 1.

За ознакою відходності, найбільш перспективними способами розділення сортового прокату на мірні заготовки є безвідходні способи (див. рис. 1 (1.3)) розділення сортового прокату: ломка згином (див. рис. 1 (2.2)), відрізка зсувом (див. рис. 1 (2.3)). Протягом багатьох років проведена велика робота 3 вивчення і вдосконалення способів ломки згином (див. рис. 1 (2.2)) та відрізки зсувом (див. рис. 1 (2.3)), як на території країн-сусідів: «Мосстанкин», «ЭНИКМАШ», «МВТУ», «Кишеневский политехнический институт», в Україні: Харківський авіаційний інститут, Донецький фізико-технічний інститут, так і за кордоном: Японія, Англія, Німеччина тощо. У роботах Фінкеля В. М., Мещерина В. Т., Соловцова С. С., Тимощенко В. А. та інших розроблені основи теорії розділення, визначені оптимальні параметри процесу, запропоновані нові схеми поділу сортового прокату, створені різні обладнання і штампи [1-5].

Фінкель В. М. запропонував перспективний спосіб ломки прокату відколом (див. рис. 1 (2.1.1)). Під ломкою прокату відколом (див. рис.1 (2.1.1)) розуміють специфічний вид руйнування за схемою розтягання (див. рис.1 (2.1)) по типу відриву в результаті інтенсивного ударного навантаження (див. рис.1 (3.3)). Короткий імпульс (див. рис.1 (3.4)), створюваний на одній з поверхонь прокату високошвидкісним зіткненням, поширюється вглиб i, досягнувши вільної поверхні, відбивається у вигляді хвилі розтягання (див. рис. 1 (2.1)). При перевищенні амплітуди напружень у відбитій хвилі тимчасового опору матеріалу на розтягання, в зоні концентратора напружень відбувається руйнування. До переваг ломки прокату відколом відносять: високу продуктивність процесу внаслідок можливості множинного відколу; ударний характер навантаження (що дозволяє досить легко одержувати напруження, які перевищують границю міцності); однорідність напруженого стану в поперечному перерізі прокату, що сприятливо впливає на якість торця заготовки; можливість одержання коротких заготовок. 


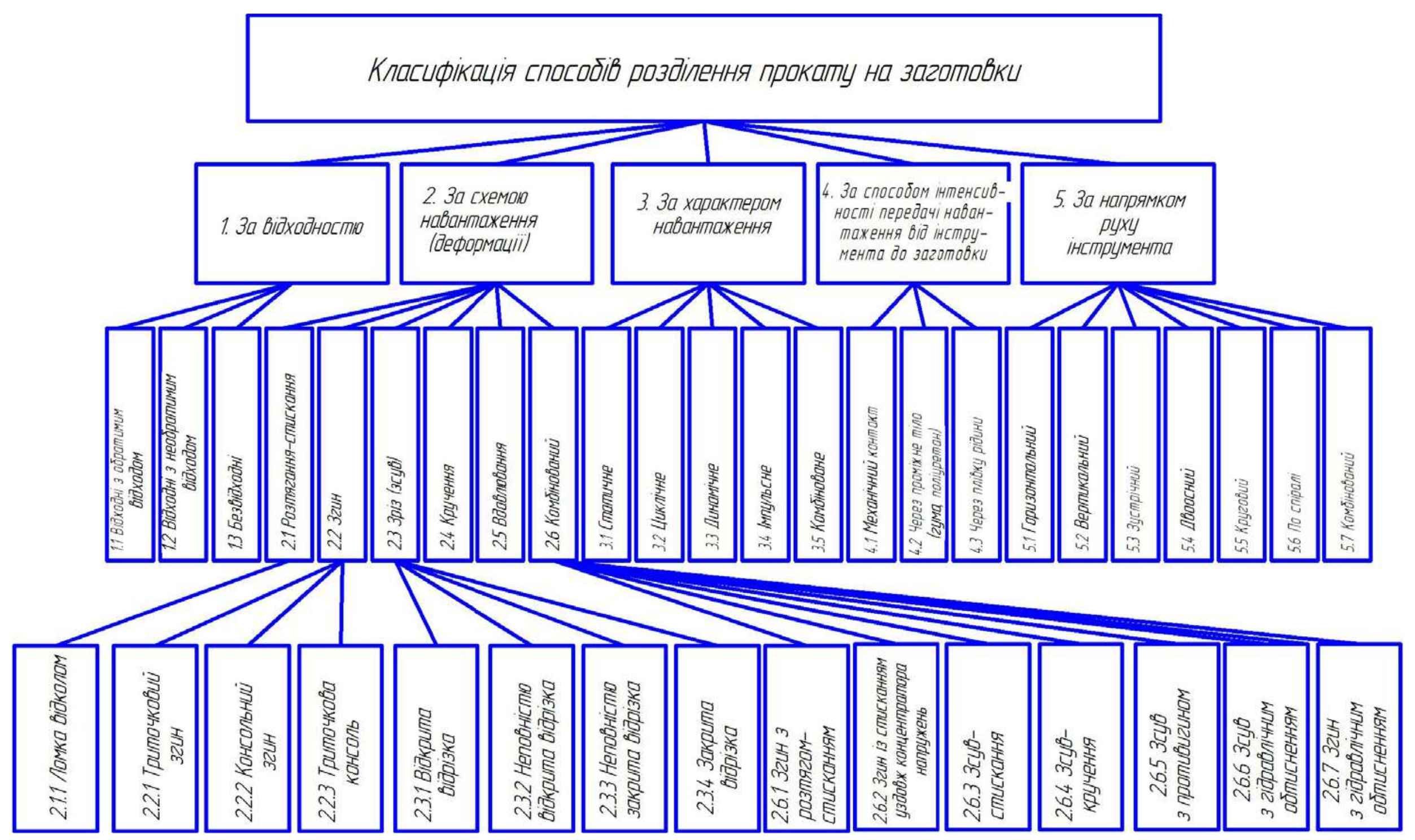


Даний спосіб можна використовувати для одержання, як одиничних заготовок, так і одночасного поділу всієї штанги прокату на велику кількість заготовок, як за рахунок одного ударного імпульсу великої амплітуди, так і за рахунок повторних імпульсів розтягання малої тривалості.

Однак спосіб ломки прокату відколом не знайшов застосування в промисловості насамперед внаслідок його невивченості й необхідності забезпечення високих значень швидкостей удару. Наприклад, для поділу прокату зі сталі 45 з кільцевим концентратором напружень 3 параметрами: глибиною 2 мм і радіусом закруглення 0,1 мм - при кімнатній температурі швидкість удару перевищує $120 \mathrm{~m} / \mathrm{c}$. Однак практично вже при швидкості удару близько 10 м/с на ударному кінці стрижня розвивається локальна пластична деформація. Даний спосіб складно реалізувати конструктивно [2].

Результати динамічної (див. рис. 1 (3.3)) ломки згином показали, що точність і якість заготовок істотно залежать від способу й інтенсивності передачі їм зусилля. Удар по прокату твердим пуансоном (див. рис. 1 (2.2.1)) (у випадку механічного контакту див. рис. 1 (4.1)) приводить до порушення форми заготовок у зоні їхнього локального зіткнення внаслідок великих величин контактних напружень, а також до утворення сколів, виривів металу, мікроі макротріщин при поділі крихких сталей. Уведення між поверхнею прокату й інструмента проміжного середовища у вигляді прокладки (див. рис.1 (4.2)) дозволило поліпшити якість поверхні поділу й усієї заготовки в цілому. Найбільш ефективним й технологічно зручним середовищем для передачі прокату динамічного навантаження $є$ рідина (див. рис. 1 (4.3)). Перевагу варто віддати саме безопорним схемам навантаження, які виключають будь-який вид твердого контакту поверхні прокату з інструментом, що реалізовано в способах поділу ломкою прокату гідравлічним обтисненням (див. рис. 1 (2.6.6,2.6.7)).

На підставі вище вказаного запропонована конструкція установки для розділення труб на мірні заготовки (рис. 2).

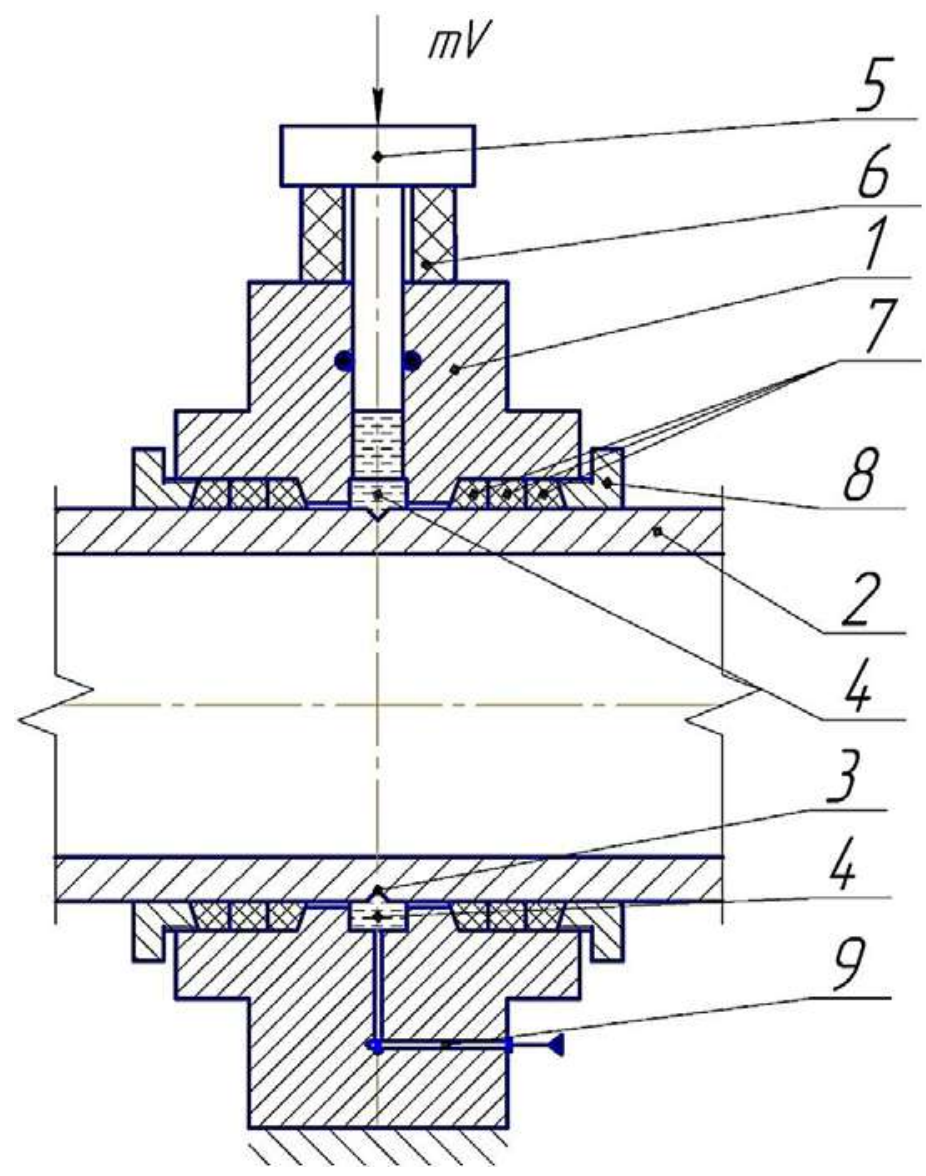

Рис. 2. Установка для розділення труб на мірні заготовки 
Установка складається із корпусу 1, в отворі якого розміщується труба 2 з попередньо нанесеним концентратором напружень 3 таким чином, щоб концентратор напружень 3 знаходився напроти порожнини 4 у корпусі 1.

У порожнині 4 розміщується ударний шток 5 з можливістю зворотно-поступального руху під дією імпульсу удару $m V$ з боку молоту. Для повернення штока 5 у вихідне положення, концентрично штоку розміщується буфер 6. Концентратор напружень 3 - це місце наведеної магістральної тріщини, яка гарантує розділення труби саме за заданою траєкторією. Для ущільнення порожнини 4 використовується комплект фторопластових кілець 7 , які піджимаються в осьовому напрямку грундбуксами 8.

Установка працює у такий спосіб. В порожнину 4 по каналу 9 подається робоча рідина під тиском. Молот наносить удар $(m V)$ по ударному штоку 5 , який розганяється і створює гідродинамічний тиск у порожнині 4. Таким чином, у порожнині 4, яка охоплює зовнішню поверхню труби 2, створюється гідродинамічний тиск, що викликає у стінці труби пружнонапружений стан та виникнення напружень розтягу. Коли напруження досягає границі міцності $\sigma_{B}$, труба розділяється. Тиск у порожнині 4 падає до 0, ударний шток 5 повертається у вихідне положення під дією сили буфера 6. Труба подається на крок, який відповідає довжині відламаної заготовки. При цьому конструкція установки має недоліки: невисока продуктивність процесу ломки, розділення лише одиночних заготовок.

Для виправлення вищеназваних недоліків запропоновано новий спосіб ломки труб та установка для його реалізації (рис. 3).

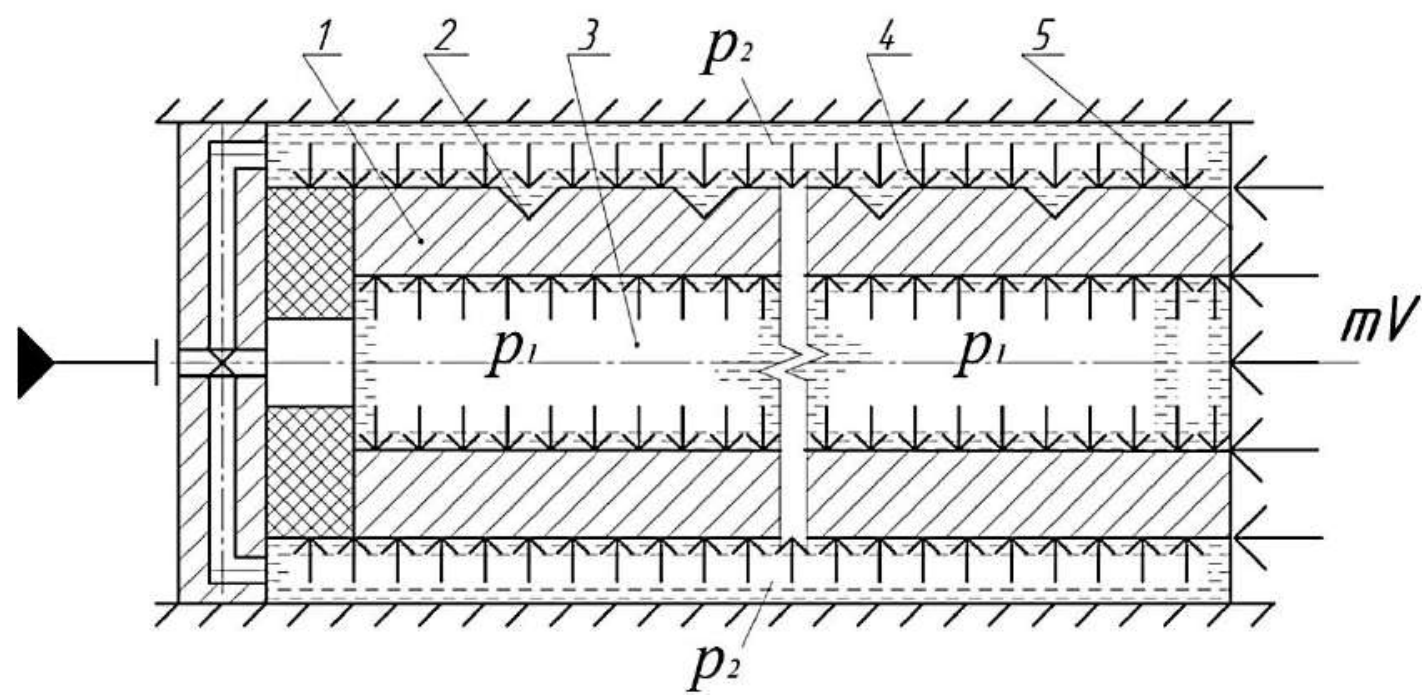

Рис. 3. Установка для розділення труб для реалізації нового способу поділу [6]

Труба 1 з попередньо нанесеними множинними концентраторами напружень 2 розміщується у робочій камері. До внутрішньої 3 і зовнішньої 4 поверхонь труби 1 подають рідину під тиском. Після цього на одному з торців 5 збуджують ударну хвилю стиску. Під дією ударного імпульсу сили $m V$ труба 1 переміщується в робочій камері і створює гідродинамічний тиск на внутрішній 3 і зовнішній 4 поверхнях труби 1. Рідина в площині концентратора напружень 2 створює одночасно, як осьові напруження розтягу, так і радіальні напруження стиску, що забезпечує стабілізацію траєкторії тріщини. При цьому рідина під тиском проникає в найменші пори, що створює додаткове розклинювання, яке сприятиме появі тріщини, що знижує енергосилові параметри процесу ломки. Одночасно ударна хвиля стиску, поширюючись до другого торця труби 1 і відбиваючись від нього, перетворюється в хвилю розтягування, яка швидко стає плоскою, з фронтом по перетину заготовки ортогональним поверхні. У трубі в зоні концентраторів 2 утворюється складний напружений стан, що приводить до поділу труби на мірні заготовки (множинна ломка). 
Спільний вплив на заготовку гідродинамічного тиску і поздовжньої хвилі стиску дозволяє знизити приблизно на $20 . . .30 \%$ величину тиску в робочій камері, спростити конструкцію вузлів ущільнення, що позитивно позначається на надійності роботи установки. Скорочується час повного циклу при реалізації даного способу, оскільки за один удар по торцю 5 здійснюється, як створення гідродинамічного тиску на зовнішній 4 та внутрішній 3 поверхнях труби і повздовжньої хвилі стиску, так і ломка прокату.

Загальний теоретичний аналіз напруженого стану процесів холодної ломки згином (див. рис. 1 (2.2)) і відрізки зсувом (див. рис. 1 (2.3)) виявляє, що вони розрізняються за своєю фізичною природою й одночасно доповнюють один одного. Тому доцільним представляється об'єднання двох процесів в одному (див. рис. 1 (2.6)), компенсуючи недоліки одного перевагами іншого. У роботі [7] запропоновано новий спосіб поділу сортового прокату за схемою «зсув-ломка». Сутність способу полягає в тому, що на першому етапі на прокат наноситься об'ємний концентратор напружень за рахунок часткового зсуву частини прокату щодо профілю на певну величину. На другому етапі прокат навантажують згинаючою силою до руйнування в площині концентратора напружень. Спосіб реалізований на установці (рис. 4).

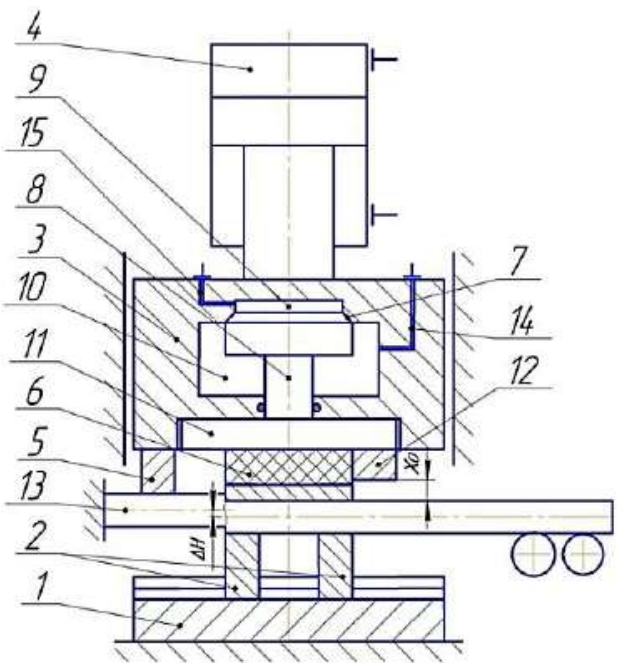

Рис. 4. Установка для розділення прокату [8]

Під дією сили з боку робочого гідропружного циліндра 4, рухома траверса 3 , на якій закріплено ломатель 5, рухається вниз, здійснюючи затиск, за допомогою пружного елемента 6, і ломку прокату 13 в площині попередньо нанесеного концентратора напружень. У момент руйнування прокату в площині концентратору напружень відбувається різке скидання сили розділення. Система «гідропружний циліндр 4 - рухома траверса 3 - ломатель 5» стає динамічно неврівноваженою. Тому рухома траверса 3 разом з ножем 12 розганяється на ході $x_{0}$ і наносить на прокат концентратор напружень за рахунок радіального зсуву частини прокату відносно осі заготовки на величину $\Delta H$. Одночасно спрацьовує гідропружний циліндр 4. Поршень 8 прискорено рухається вниз, разом з бойком 11 і ножем 12, та додає енергії для нанесення концентратора напружень.

Таким чином, потенційна енергія, накопичена в установці за рахунок пружної деформації станини і приводу, та потенційна енергії стислої робочої рідини додаткового гідропружного циліндру переходить у кінетичну енергію і витрачається на здійснення корисної роботи - нанесення концентратора напружень. Установка статичної дії працює в динамічному режимі, що забезпечує підвищену швидкість нанесення концентратора напружень і високу якість отриманих заготовок.

Можливість попереднього статичного навантаження (див. рис. 1 (3.1)), у сполученні з високою швидкістю деформування (див. рис. 1 (3.3)), дозволяє створити у прокаті схему напруженого стану, яка забезпечує необхідну геометричну точність і якість заготовок. На цій підставі запропоновано новий спосіб розділення прокату (рис. 5). 


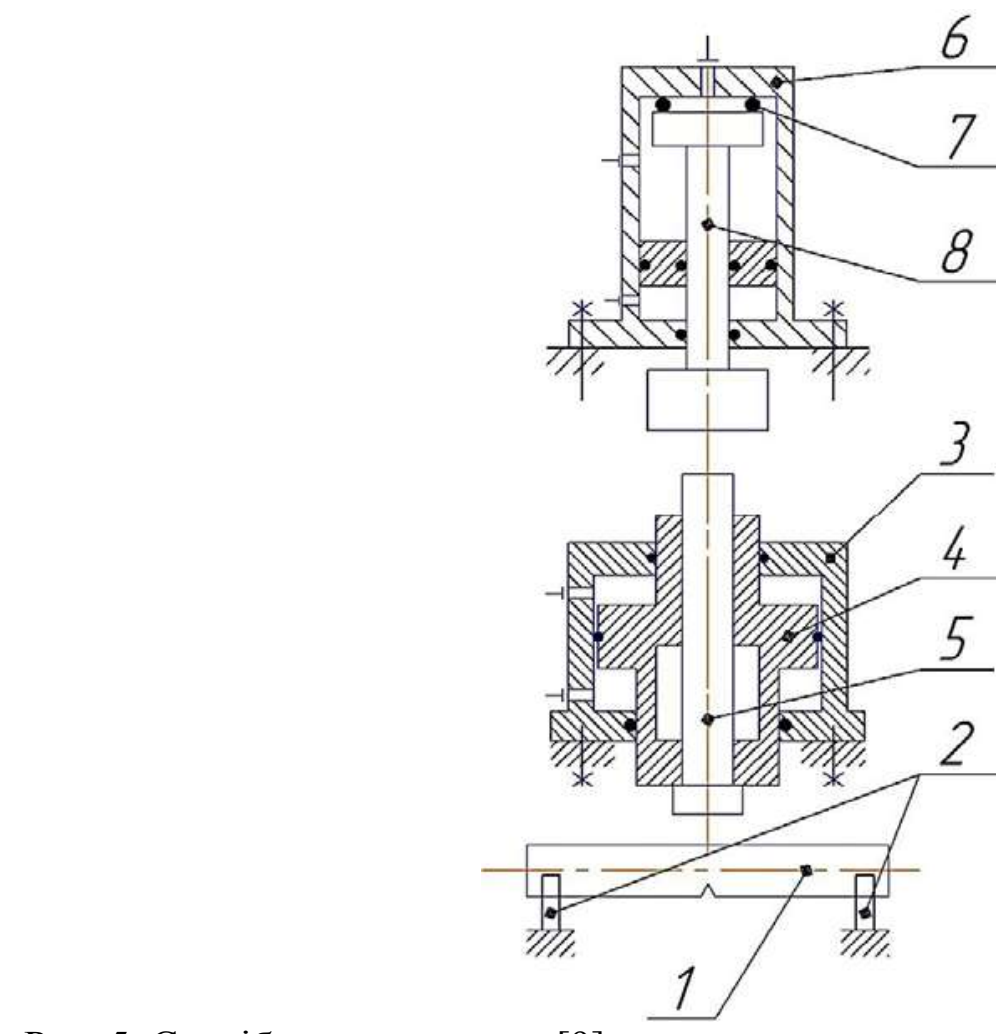

Рис. 5. Спосіб ломки прокату [9]

Прокат 1 з попередньо нанесеним концентратором напружень розміщується на опорах 2 і подається до упору. Під дією сили з боку робочого гідроциліндра 3, поршень 4 переміщується вниз разом 3 проміжним пуансоном 5. При цьому прокат 1 попередньо навантажується статичною силою, за рахунок чого вибираються зазори між прокатом 1, опорами 2 і проміжним пуансоном 5. Після цього прокат 1 навантажується динамічною силою з боку гідропружного циліндра 6. Це можливо за рахунок різкого вивільнення потенційної енергії пружної деформації рідини у циліндрі 6 через клапан 7. При цьому шток 8 розганяється і наносить удар по проміжному пуансону 5 , здійснюючи розділення прокату 1 на заготовки. Після чого поршень 4, проміжний пуансон 5 і шток 8 повертаються у початкове положення. Застосування пропонованого способу дозволяє підвищити якість заготовок.

Даний спосіб також може бути реалізований за допомогою прес-молоту (рис. 6).

При робочому ході клина 6, шарнір 7, повертаючись щодо своєї осі на робочий кут, переміщує вниз по напрямним рухому траверсу 8. При цьому відбувається статичне навантаження прокату. Після набору тиску в порожнині 4 циліндра 2 рідиною, що подається по каналу 12 поршень 9 переміщується вгору до упору і займає вихідне положення. Далі рідину подають у порожнину низького тиску 5 під кільцеве ущільнення 10 по каналу 13. При цьому шток 3 з бойком 16 відривається від кільцевого ущільнення 10 і розганяється енергією гідравлічною пружини та наносить удар по проміжній проставці 17. У процесі удару здійснюється статико-динамічне навантаження на прокат та розділення заготовки. Після удару і відскоку бойка 16 за рахунок додаткової деформації заготовки технологічна сила на рухому траверсу 8 знижується або знімається повністю.

Запропонована конструкція пристрою дозволяє підвищити ефективність використання обладнання для розділювальних операцій, коефіцієнт корисної дії. Це стало можливим тому, що клиношарнірний механізм з увігнутим клином має графік зміни сили навантаження, найбільш наближений до технологічного типового графіка зміни сили при відрізуванні. В результаті чого в момент розділення сила з боку клиношарнірного механізму з увігнутим клином максимальна і далі зменшується по ходу клина. При цьому хоч і неможливо повністю усунути різке скидання технологічного навантаження в момент поділу, але величина шкідливої енергії розвантаження обладнання при цьому буде значно менша. Підвищується коефіцієнт корисної 
дії та надійність роботи обладнання. Застосування статико-динамічного навантаження (див. рис. 1 (3.5)) дозволяє підвищити якість заготовок, що поділяються, за рахунок створення у прокаті оптимальної схеми напруженого стану. Спільне застосування клиношарнірного і гідропружного приводів дозволяє усунути заклинювання і знизити необхідну потужність приводу.

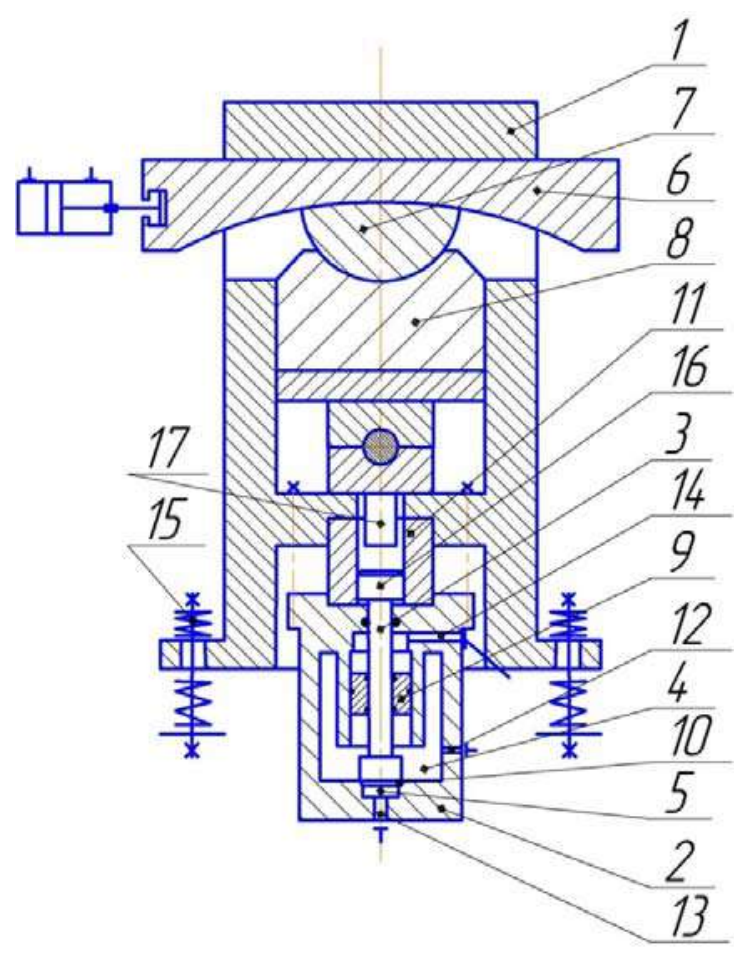

Рис. 6. Прес-молот з клиношарнірним механізмом з увігнутим клином [10]

Стає можливим використовувати привід при малих кутах клина, що підвищує силу технологічного навантаження, оскільки ударне деформування заготовки за допомогою гідропружного циліндру знімає навантаження 3 клиношарнірного механізму. Поєднання клиношарнірного і гідропружного приводів забезпечує зниження енергії удару, підвищення стійкості інструменту.

Одним 3 напрямків підвищення якості заготовок є створення способів навантаження, яким органічно властивий однорідний напружений стан. Із цією метою розроблена конструкція установки для поділу прокату ломкою згином (рис. 7).
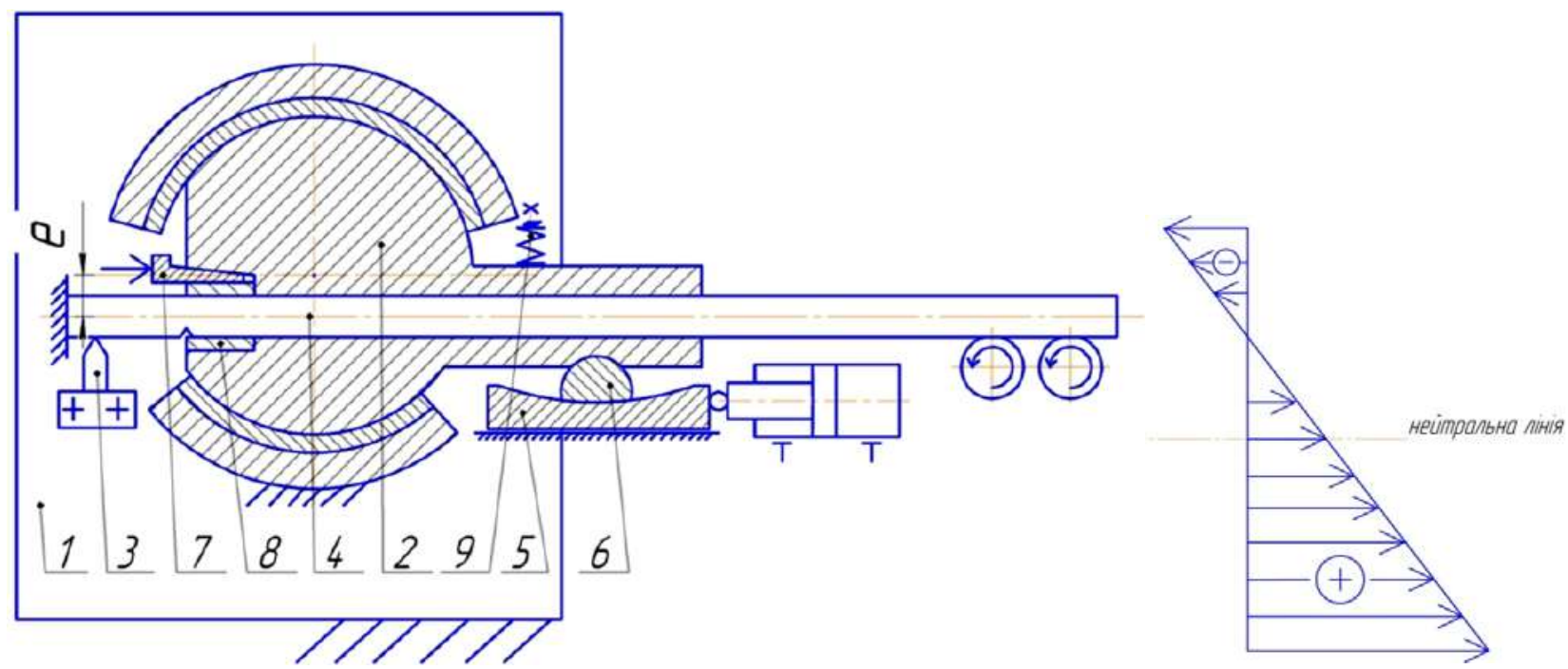

Рис. 7. Установка для ломки прокату згином [11] 
Сутність запропонованих рішень полягає в тому, що зона напружень розтягу (див. рис. 1 (2.1)) збільшується за рахунок зони напружень стиску. Оскільки основною причиною нестабільності тріщини є близькість їі вершини до нейтральної лінії, що рухається перед нею і за якою розташована зона напружень стиску, орієнтованих нормально до площини поділу, збільшення зони напружень розтягу за рахунок зміщення осі ломателя від осі прокату на величину ексцентриситету е, дозволяє стабілізувати траєкторію тріщини та підвищити якість заготовок, що поділяються. Прокат з попередньо нанесеним концентратором напружень вводять в отвір ломателя 2 до упору і затискають механізмом затиску за рахунок переміщення клина 7, який розклинює систему «клин 7 - напіввтулки 8 - прокат 4». За рахунок сили приводу, клин 5 діє на шарнір 6, який повертається навколо своєї осі і передає силу на ломатель 2, що обертається, здійснюючи згин і розділення прокату у площині концентратору напружень. При цьому застосування клиношарнірного механізму з увігнутим клином дозволяє забезпечити максимальну силу на піку навантаження, яка далі зменшується по ходу клина. Підвищується коефіцієнт корисної дії та надійність роботи обладнання.

Запропоновано нову конструкцію пристрою (рис. 8), в якому нанесення концентратора напружень і розділення здійснюється у вертикальній площині за один робочий хід.

Прокат подають на необхідну величину в зазор між розведеними ножами 1 i 2 . Ніж 1 перед початком різання знаходиться в крайньому верхньому положенні, ніж 2 - в крайньому нижньому. Після подачі заготовки одночасно включаються приводи ножів 1, 2, кожний із яких приводиться у рух за допомогою гідроциліндрів поршневого типу 9, штоки яких діють на клини 7. Клини 7 взаємодіють 3 шарнірами 8, які повертаються відносно своєї осі і передають рух і навантаження до ножів 1, 2, які переміщуються вертикально. У процесі здійснення ножами 1, 2 зустрічного руху у вертикальному напрямку, відбувається зменшення відстані по горизонталі між ріжучими кромками 3, 4. Ножі 1, 2, обертаючи заготовку, поступово відрізають іiі, аж до моменту відділення, а притискні кромки 5, 6 протягом всього процесу відрізки здійснюють жорсткий притиск прокату.

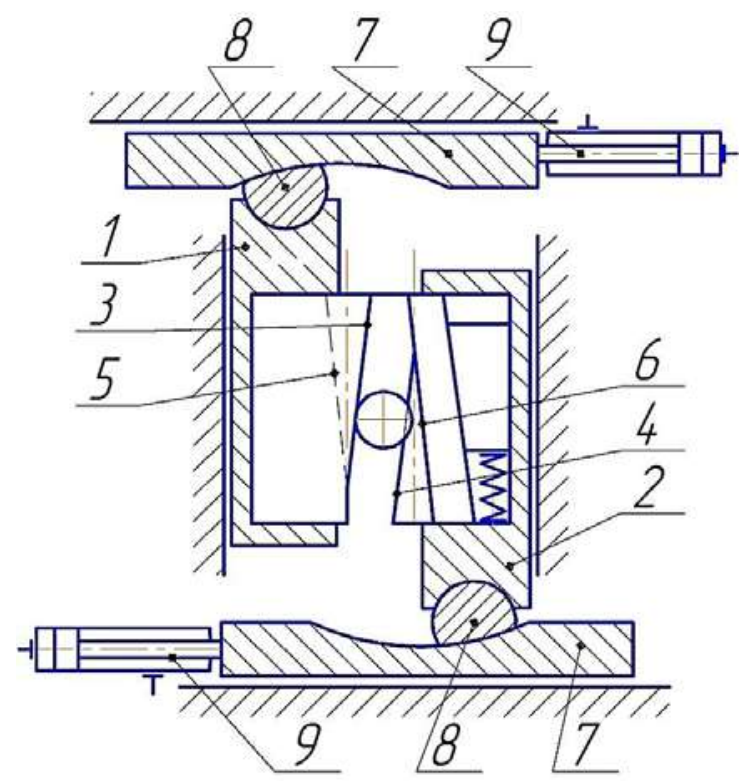

Рис. 8. Пристрій для відрізки прокату [12]

При застосуванні пристрою забезпечується надійна робота і висока якість заготовок, що поділяються, розширюються технологічні можливості.

Для подальшого розширення технологічних можливостей обладнання для розділення сортового прокату, запропонована нова конструкція клиношарнірного пресу (рис. 9).

За допомогою гідроциліндра 8 приводиться в рух клин 4 силою $F_{\Gamma}$. Рух від клина 4 через шарнір 3 передається до повзуна 2 , який здійснює робочий хід вертикальною силою $F_{B}$. 
Запропонована конструкція пресу дозволяє змінювати величину нахилу клина преса. Змінюючи у клиношарнірному механізмі кути нахилу клина i шарніра, можна отримати різний характер зміни відношення приводної і технологічної сил, що дозволяє для різних операцій обробки металів тиском підібрати конструкцію і режим роботи клиношарнірного механізму, які найбільше відповідають графікам технологічних сил.

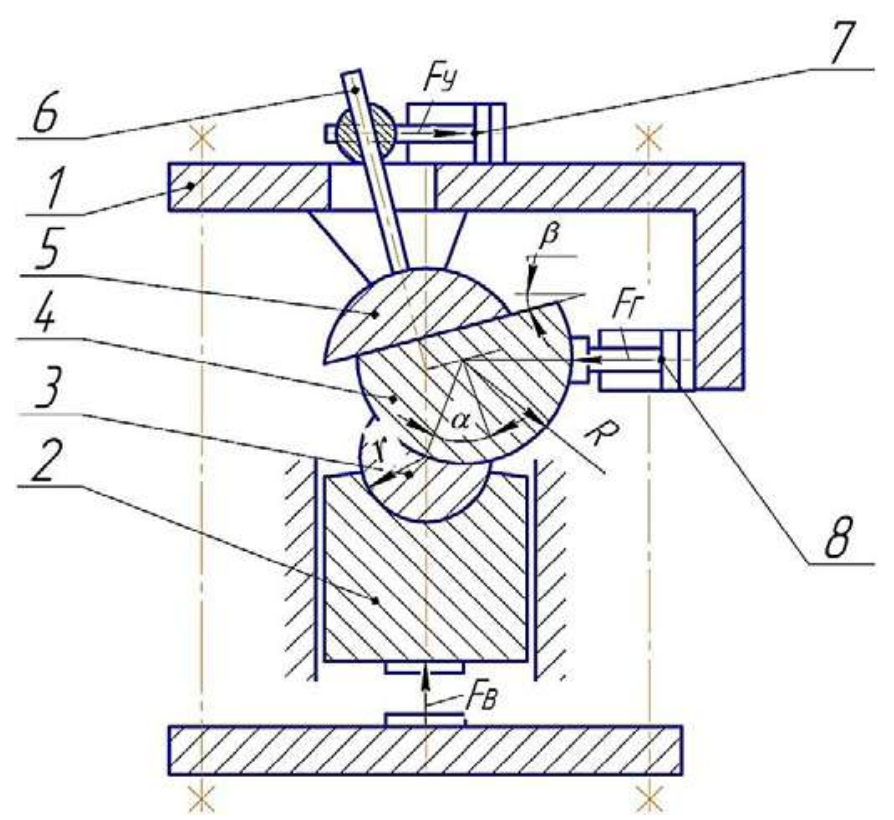

Рис. 9. Клиношарнірний прес [13]

\section{ВИСНОВКИ}

1. Запропонований новий спосіб розділення сортового прокату (труб), в якому потенційна енергія деформації деталей і приводу обладнання витрачається на здійснення корисної роботи - нанесення концентратора напружень за один робочий хід. Обладнання статичної дії працює в динамічному режимі, що забезпечує високу якість отриманих заготовок.

2. Можливість попереднього статичного навантаження, у сполученні з високою швидкістю деформування, дозволяє створити у прокаті схему напруженого стану, яка забезпечує необхідну геометричну точність і якість заготовок.

3. Розроблено спосіб ломки прокату, в якому зона напружень розтягу збільшується за рахунок зони напружень стиску, що створює схему навантаження, якій органічно властивий однорідний напружений стан. Це дозволяє стабілізувати траєкторію тріщини та підвищити якість заготовок, що поділяються.

4. Запропоновано спосіб гідродинамічної ломки прокату, в якому в зоні концентраторів напружень утворюється складний напружений стан, що приводить до поділу труби на мірні заготовки (множинна ломка). Спільний вплив на заготовку гідродинамічного тиску і поздовжньої хвилі стиску дозволяє знизити величину тиску в робочій камері, спростити конструкцію вузлів ущільнення, що підвищує надійність роботи обладнання.

5. Запропонована конструкція обладнання, в якому спільне застосування клиношарнірного і гідропружного приводів дозволяє усунути заклинювання і знизити необхідну потужність приводу. Це стало можливим тому, що в момент розділення сила з боку клиношарнірного механізму з увігнутим клином максимальна і далі зменшується по ходу клина. При цьому хоч і неможливо повністю усунути різке скидання технологічного навантаження в момент поділу, але величина шкідливої енергії розвантаження обладнання при цьому буде значно менша. Підвищується коефіцієнт корисної дії та надійність роботи обладнання. Застосування статико-динамічного навантаження дозволяє підвищити якість заготовок, що поділяються, за рахунок створення у прокаті оптимальної схеми напруженого стану. 


\section{СПИСОК ВИКОРИСТАНОЇ ЛІТЕРАТУРИ}

1. Веселовский С. И. Разрезка материалов. Москва : Машиностроение, 1973. 360 с.

2. Финкель В. М., Головин Ю. И., Родюков Г. Б. Холодная ломка проката. Москва : Металлургия, 1982. 192 c.

3. Соловцов С. С. Безотходная разрезка сортового проката в штампах. Москва : Машиностроение, 1985. $176 \mathrm{c}$.

4. Роганов Л. Л., Карнаух С. Г., Карнаух Д. С. Анализ технологий и оборудования для разделения труб на мерные заготовки. Сообщение 1. Обработка материалов давленим. Краматорск : ДГМА, 2013. № 1 (34). C. $120-128$.

5. Роганов Л. Л., Карнаух С. Г., Карнаух Д. С. Разработка новых конструкций оборудования и оснастки для разделения труб на мерные заготовки. Сообщение 2. Обработка материалов давлением. Краматорск : ДГМА, 2013. № 2 (35). С. 147-153.

6. Карнаух С. Г., Карнаух Д. С., Чоста Н. В. Спосіб ломки труб: патент 107698 Україна: В 23D 27/00. 2016, Бюл. № 12.

7. Карнаух С. Г. Совершенствование безотходных способов разделения сортового проката и оборудования для получения заготовок высокого качества : монографія. Краматорск : ДГМА, 2010. 196 с.

8. Карнаух С. Г., Карнаух Д. С. Спосіб розділення прокату: патент 116199 Україна: В 23D 23/00. B21B 1/02. 2017, Бюл. № 9.

9. Карнаух С. Г. Спосіб ломання прокату: патент 130634 Україна: В 23D 23/00. 2018, Бюл. № 24.

10. Карнаух С. Г., Карнаух Д. С., Чоста Н. В., Коляденко А. В. Прес-молот з клиношарнірним механізмом з увігнутим клином: патент 111267 Україна: В 30В 1/00. 2016, Бюл. № 21.

11. Карнаух С. Г., Карнаух Д. С. Пристрій для ломки прокату згином: патент 112669 Україна: В 23D 31/00. В 23D 23/00. 2016, Бюл. № 24.

12. Карнаух С. Г. Пристрій для відрізки прокату: патент 125304 Україна: В 23D 15/00. 2018, Бюл. № 9.

13. Карнаух С. Г., Чоста Н. В. Клиновий прес: патент 134608 Україна: B23D 23/00. 2019, Бюл. № 10.

\section{REFERENCES}

1.Veselovsky 1.S. Material cutting. Moscow: Mechanical Engineering. 1973, 360 p. (in Russian).

2. Finkel V.M., Golovin Yu.I., Rodyukov G.B. Cold breaking of rolled metal. Moscow: Metallurgy. 1982, 192 p. (in Russian). (in Russian)

3. Solovtsov S.S. Non-waste cutting of long products in stamps. Moscow: Mechanical Engineering. 1985, 176 p.

4. Roganov L.L., Karnaukh S.G., Karnaukh D.S. Analysis of technologies and equipment for separating pipes into measured billets. Message 1. Material Working by Pressure. Kramatorsk: DSEA. 2013, 1 (34), pp. $120-128$. (in Russian).

5. Roganov L.L., Karnaukh S.G., Karnaukh D.S. Development of new equipment and tool designs for dividing pipes into measured billets. Communication 2. Material Working by Pressure. Kramatorsk: DSEA. 2013,2 (35), pp. 147-153. (in Russian).

6. Karnaukh S.G., Karnaukh D.S., Chosta N.V. Method for breaking pipes. Patent Ukraine 107698. 2016. (in Ukrainian).

7. Karnaukh S.G. Improvement of non-waste methods of separation of long products and equipment for producing high-quality billets: monograph. Kramatorsk: DGMA. 2010, 196 p. (in Russian).

8. Karnaukh S.G., Karnaukh D.S. A method of dividing the rental. Patent Ukraine 116199. 2017. (in Ukrainian).

9. Karnaukh S.G. A method of rolling hire. Patent Ukraine 130634. 2018. (in Ukrainian).

10. Karnaukh S.G., Karnaukh D.S., Chosta N.V., Kolyadenko A.V. A press hammer with a wedge-shaped mechanism with a concave wedge. Patent Ukraine 111267. 2016. (in Ukrainian).

11. Karnaukh S.G., Karnaukh D.S. A device for breaking a bend by a bend. Patent Ukraine 112669. 2016. (in Ukrainian).

12. Karnaukh S.G. Roller cutter. Patent Ukraine 125304. 2018. (in Ukrainian).

13. Karnaukh S.G., Chosta N.V. Wedge press. Patent Ukraine 134608. 2019. (in Ukrainian).

Карнаух С. Г. - канд. техн. наук, доц., зав. каф. ОПМ ДДМА.

ДДМА - Донбаська державна машинобудівна академія, м. Краматорськ.

E-mail: k_sergii@i.ua 